\title{
Critical Factors Influencing e-Government Adoption in The Gambia
}

\author{
Malang B.S. Bojang \\ Political Science and Public Administration Department, Faculty of Economics and Administrative Sciences, \\ Umuttepe Campus, Kocaeli University, Kocaeli, Turkey. \\ Email: malangbsbojang@gmail.com \\ https://riiopenjournals.com/index.php/society sustainability/index
}

Doi:https://doi.org/10.38157/society_sustainability.v3i1.232

Citation: Bojang, M.B.S.(2021). Critical Factors Influencing e-Government Adoption in The Gambia, Society \& Sustainability, 3(1), 39-51. Doi: https://doi.org/10.38157/society_sustainability.v3i1.232

\section{Research Article}

\begin{abstract}
e-Government is a prerequisite not only for meeting citizen's needs but also creating the background for the development of knowledge-based public administration. Yet, e-Government development is still at the infancy stage in many developing countries. The objective of this paper is to identify critical factors that enable citizens to adopt e-Government services in a society that is at the infancy stage of e-Government implementation. In other words, this research seeks to determine citizens' intentions to adopt eGovernment initiatives in The Gambia. To achieve the purpose of the study, an integrated model from DeLone and McLean (2003) and Bojang (2020) has been adopted having in mind the local context of Gambian society. Using a quantitative approach, online surveys and secondary data were collected and analyzed descriptively. The findings from the survey concluded that awareness creation and quality service provision strongly influence citizens' intention to adopt e-government services. Political and bureaucratic support and trust in government were also found to be critical factors for the adoption of eGovernment in The Gambia. The availability of information, ease to use of government websites, up-todate information, reliability and quick response from government websites equally influence citizens' intention to adopt e-Government. This study will help policy-makers to initiate and formulate policies, strategies that will increase the adoption of e-Government initiatives among citizens.
\end{abstract}

Keywords: The Gambia; e-Government adoption; e-Participation; e-Readiness; e-Services.

\section{Introduction}

Over the past decade, public administration has witnessed enormous transformations and reforms. One such reform is the integration of technology in the administrative systems of government. With the advancement in Information and Communication Technologies (ICTs), governments adopt web-based technologies to deliver quality services to their citizens. Electronic government (henceforth e-Government) as a reform tool in public administration has become a global trend to deliver quality public services to the citizens and at the same time 
make the government more open, effective, and efficient in handling the day-to-day affairs of the state. e-Government inherits the administrative reform inspired by New Public Management (NPM) which was implemented in the 1980s (Torres et al., 2005). e-Government is a complex phenomenon with multiple challenges especially for developing African countries, where public sector managers share responsibility for model selection, adoption, and achieving the benefits of e-Government initiatives (Rose et al., 2015). The public sector plays a significant role in the efficient delivery of public services (Sæbø, 2012) and the use of ICTs makes it even better. With the rapid technological evolution, the scale of investment is huge in terms of adoption, information systems, and infrastructure. The administrative challenge is correspondingly massive, responding to citizens' and businesses' expectations (Rose et al., 2015). Most governments are still faced with classical administrative attributes such as centralized decision-making patterns, red tape, redundancies in the public sector, inadequate coordination, and information sharing in the public sector (Rehman et al., 2012; Srivastava \& Teo, 2008). With these troubles, governments are making effort towards improving the process of providing quality and timely services to the citizens through e-Government. For the successful adoption of e-Government, citizens' ability, and willingness to use e-Service are paramount.

In July 2003, The Gambia imploring the support from United Nations Economic Commission for Africa (UNECA) and the African Information Society Initiative (AISI), embarked on a baseline study assessing the e-Readiness status of the country to develop and design an eGovernment strategy(Chango, 2007; Gambia e-Government Strategy Report, 2003). The report of the survey was validated in a workshop held in Banjul on October, 17th 2003. Legal framework, ICT infrastructures, government interface, applications, portals, legislation relating to public information management, and web development were key themes discussed. It was until 2005 (Lin et al., 2011) that the Government of The Gambia promoted an e-Government initiative. The Gambia has recognized the transformational opportunities e-Government offered in effective and timely service delivery to the citizens. The Gambia government sees eGovernment as a tool to improve the quality of life of Gambians and to fight against poverty (Gambia e-Government Strategy Report, 2003). However, little research is done on Gambia's eGovernment initiatives and none on factors influencing citizens' adoption of e-Government. To address this situation, the objective of this paper is to identify critical factors that enable citizens to adopt e-Government services in a society that is at an infancy stage of e-Government implementation. This study also seeks to determine citizens' intentions to adopt e-Government initiatives in The Gambia. To achieve the purpose of this study, an integrated model from (DeLone \& McLean, 2003) and (Bojang, 2020) has been adopted having in mind the local context of Gambian society.

\section{Literature review: e-Government adoption}

e-Government, which in this study refers to the use of ICTs to promote more efficient and effective government, facilitate more accessible government services, allow greater public access to information, and make government more accountable to citizens. These services might be delivered through integrated e-Government platforms: the internet, telephone, community 
centers, wireless devices, or other communications systems (Ceesay \& Bojang, 2020). As a public sector reform strategy, e-Government promises are huge and these have made it globally accepted by world governments aiming for better governance and quality delivery of public services.

Despite the popularity of e-Government, many developing countries are at the infancy stage of adoption. It is often argued that e-Government benefits do not reflect the real situation on the ground or rather an evidence of its effectiveness is difficult to notice (Bakunzibake et al., 2019; Kearns, 2004). In other words, e-Government initiatives failed to provide the intended benefits especially in developing African countries. Partly, the technological infrastructure and social aspect could be blamed for these failures (Bakunzibake et al., 2019). Heeks has argued that 85\% of e-Government initiatives in developing countries can either be categorized as total or partial failures (Heeks, 2002). Not only this figure is high but also the resource burden on developing countries in implementing an innovative system in an environment with meager resources is problematic. Even though there is a high failure rate of e-Government projects, economically underdeveloped countries including The Gambia have started adopting e-Government services. For e-Government adoption to be successful, a formalized approach is required to help the relevant stakeholders understand e-Government from infancy to maturity. Various eGovernment roadmap models for implementation have been emphasized. For example, the United Nations five-stage e-Government model, Layne and Lee four-stage e-Government model, Gartner four-stage e-Government model, and World Bank three phases e-Government model (Magayane et al., 2016). The adoption of information systems focused on identifying elements that determine this process. The dual models of facilitators and inhibitors which centered on intention and behavior effect have been gaining significance (Rey-Moreno \& Medina-Molina, 2017). User behavior which is influenced by users' intentions, beliefs, trust, and attitudes, helps in defining the explanatory models of e-Government adoption. In such models, it is believed that citizens' high intentions to use e-Government will spur the adoption of eGovernment. There have been a plethora of models explaining users' acceptance of a technology and e-Government adoption - for example, the Technology Acceptance Model (TAM), Diffusion of Innovation (DOI), and DeLone and McLean Information System success model (Rehman et al., 2012). However, previous models failed to explain vividly the adoption of e-Government (Rey-Moreno \& Medina-Molina, 2017) in developing countries. This study would rather argue that existing models be complementary in explaining failures of e-Government adoption from the citizens' perspective.

Studies have indicated that the adoption of e-Government is related to the size of government, level, and form of administration and region (Holden et al., 2003). Other studies have come up with a plethora of factors influencing citizen adoption of e-Government. Perceived relative benefits, government support, perceived barriers, visual appeal, experience, financial security, information quality, low stress, and trust were all compelling factors found to be influencing the successful adoption of e-Government (Rehman et al., 2012). According to the model proposed by (DeLone \& McLean, 2003) and (Bojang, 2020), critical factors influencing the adoption of eGovernment were information quality, system quality, service quality, use, user satisfaction and

41 Published by Research E Innovation Initiative, 3112 Jarvis Ave, Warren, MI 48091, USA 
perceived net benefit, e-Government sensitization, awareness, and e-Lifestyle, citizen trust, political will, stakeholder and private sector support, readiness and willingness of bureaucrats to adopt new technologies (Bojang, 2020). The study by (Rey-Moreno \& Medina-Molina, 2017) identified organizational support, self-efficacy, benefits, loss aversion, regret aversion, control, transition costs, sunk costs/switching costs, uncertainty, habit, resistance, and inertia as inhibitors to citizens' adoption of e-Government (Rey-Moreno \& Medina-Molina, 2017). Further, in designing and implementing e-Government websites, the government must consider elements of policy, including regulatory issues, economic issues, and the rights of users (Jaeger \& Thompson, 2003).

In evaluating e-Government implementation strategies in Nigeria, (Ifinedo, 2005) highlights some teething problems that hinder e-Government adoption and implementation. Lack of organizational skills, inadequate awareness towards e-Government of country, poor economic situation, low teledensity were found to hinder e-Government implementation. (Ifinedo, 2005) concludes that e-Government is an elitist tool in Nigeria. The findings by (Magayane et al., 2016) depicted that the level of e-Government implementation in Tanzania was in the stages of digital presence and interaction. Contrarily, the results from (Sæbø, 2012) indicate the lack of awareness of the opportunities and potential impact of introducing e-Government in Tanzania's public sector. (Sæbø, 2012) argues that without an awareness of potential benefits, the resistance to change remains strong. In assessing implementation challenges of e-Government in Rwanda, (Twizeyimana et al., 2018) found out six overarching categories that challenge a successful implementation of e-Government in Rwanda. These include information infrastructure for eGovernment, social inclusion, governance, management, trust in the new system, and languages. Accordingly, these challenges are influenced by various contextual factors which include political support, nature of the e-Government project, implementation strategies, human and socio-economic development, existing information infrastructure, and operational capabilities (Twizeyimana et al., 2018).

\section{The Conceptual model}

The conceptual model seeks to measure citizens' intentions to use e-Government services at a different level. An integrated model from (DeLone \& McLean, 2003) and (Bojang, 2020) has been adopted in this study. The reviewed literature informs the variables used which include information quality, system quality, service quality, intention to use, user satisfaction, and perceived net benefit, e-Government sensitization, awareness and e-Lifestyle, citizen trust, political will, stakeholder and private sector support, readiness and willingness of bureaucrats to adopt new technology.

e-Government sensitization, awareness, and e-Lifestyle: e-Government has indeed become a global phenomenon, yet developing African countries are still struggling to catch up with advanced countries in terms of adoption and implementation of e-Services. To influence citizens' intentions to adopt e-Services, massive sensitization, and awareness campaign on the potential benefits of e-Government should be promoted by the government and other relevant stakeholders. Since e-Government is an imported concept from the North, awareness of its 
merits would be of great essence. This is necessary because e-Government projects should center on citizens.

Citizen trust: Over the years, citizens' trust in their government has plummeted and eGovernment is seen as a transformational tool that fosters Citizen-to-Government (C2G) relationships. Studies have indicated the relationship between citizens' adoption of eGovernment and trust and confidence in the government. Citizen-to-Government (C2G) contact could improve quality service delivery to the citizens, increase citizen satisfaction with government, and help in restoring citizen trust and confidence in their government (Morgeson et al., 2011). With citizen trust and confidence in government, the adoption of e-Government, eService will increase tremendously.

Political will, stakeholder, and private sector support: e-Government is a complex phenomenon that centers not only on technology per se but on government management and citizens. Therefore, political support is vital for the successful implementation of e-Government. The political endorsement is significant for e-Government adoption especially in Africa (Bojang, 2020). Equally, the private sector and other relevant stakeholder support in terms of technological infrastructure and human resource development will spur the adoption of eGovernment.

Readiness and willingness of bureaucrats to adopt new technology: Bui et al., (2003) defined e-Readiness as "the aptitude of an economy to use ICT to migrate traditional businesses into the new economy". To promote e-Government adoption, citizens must have unlimited access to the internet and other ICTs infrastructures. Community centers should equally be equipped with ICTs to ease the burden on people who do not have access to computers and the internet. Besides, awareness creation among public servants on the benefits of adopting new technologies will enhance the adoption of e-Government.

Information quality: To enhance e-Government adoption, the information provided by government websites must be relevant, accurate, complete, and timely. This requires providing up-to-date information for public consumption at no cost. System quality has to do with the individual impact on ICTs. It is about data quality, reliability, functionality, portability, and flexibility (DeLone \& McLean, 2003). Service quality focuses on the service provided by the government should be reliable and responsive to citizens' needs and aspirations. This means the government should plan and organize how to provide quality information 24/7 to respond to citizens' needs quickly. In return, this will enhance e-Government adoption (Rehman et al., 2012).

Intention to use: Demographic factors such as age, gender, education, internet experiences all affected the adoption of e-Government. Intention to use deals with people's attitudes which may be influenced by service quality, ease to use e-Services, privacy and security, trust in the internet, and the government. These factors will lead to user satisfaction which enhances eGovernment adoption among citizens. The perceived net benefits of e-Government are huge and it includes competitive advantage, strategic benefits, and informational benefits (Bojang, 2020). All these are critical factors influencing citizen adoption of e-Government. 


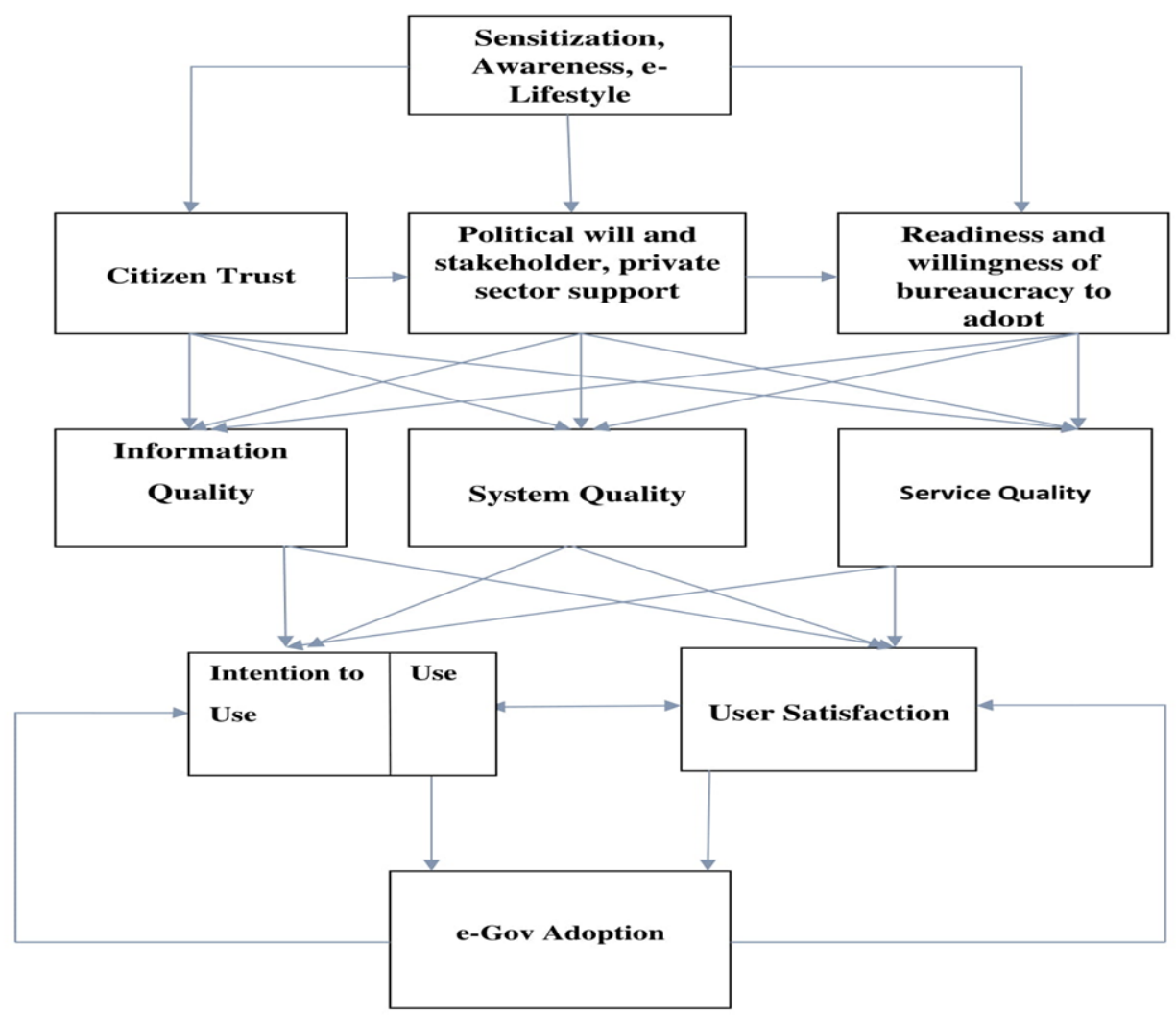

Fig. 1: The proposed alternative model for e-Government success Adopted from (DeLone \& McLean, 2003) and (Bojang, 2020)

\section{Research methodology}

The objective of this paper is to identify critical factors that enable citizens to adopt eGovernment services in The Gambia. To achieve this aim, a quantitative approach was used. The study employed a quantitative online-based survey with a descriptive analysis of the survey data. An integrated model from (DeLone \& McLean, 2003) and (Bojang, 2020) has been adopted in this study. This model informs the survey questionnaires as well as the variables used. Employing a purposive sampling strategy, data collected for this study is both secondary and primary. The primary data was collected through an online survey distributed to Gambian citizens through a web link, WhatsApp, and email. The respondents are selected via the purposive sampling method. Here the researcher has the discretion to use sample respondents who are conducive to reach. The survey consisted of two sections. Section one focused on 
demographic information of respondents and section two examined factors influencing eGovernment adoption in The Gambia. A five-point Likert-type scale questionnaire of closedended was employed in section two. The citizens' perception was measured on a five-point Likert-type scale ranging from 1 to 5 , where 1 denotes strongly disagree while 5 denotes strongly agree.

The sample population of this research was Gambian citizens who may or may not have experience of e-Government in The Gambia. A total of 200 survey questionnaires was sent via a web link, WhatsApp, and email, out of which 134 respondents' data were retrieved successfully. Data was collected from a wide range of groups which includes government civil servants, academic scholars, University and College students, and business personnel. This helps limit response bias, coupled with having a different perception from the citizens.

\section{Results}

Out of the 200 hundred respondents, 134 responses were collected successfully. From the piechart below, $73.1 \%$ of the respondents were male while $26.9 \%$ of the respondents were female; $43.3 \%$ of the participants were aged between 30-44 years whereas 30.3\% were aged between 25 29 years. $22.9 \%$ of the respondents were aged between 18-24 years, while 3.5\% were aged between 56-64 years. The majority of the respondents fall into the age ranges of 30-44 years and 25-29 years respectively. Arguably, these figures indicate that young people are more active in utilizing e-Government services than old people with 3.5\%. The majority of the respondents had an educational degree in college, and graduate. From the statistic, $43.9 \%$ of the respondents had graduate degrees while $43.9 \%$ yielded an undergraduate degree; $6.1 \%$ had a college degree, $3 \%$ secondary school certificate, and $3 \%$ professional education.

Many of the respondents were internet users with $97 \%$ of the participants claimed to use the internet daily while $3 \%$ of the respondents use the internet several times. This indicates that the majority of the respondents have internet experience. However, this high rate of internet usage among participants does not translate into the utilization of e-Government services. For example, the statistic shows that $21.5 \%$ of the respondents used e-Information or browse government website; $67.7 \%$ of the participants have either a biometric ID card or passport; downloading and filling of job application online yielded $9.2 \%$, and $20 \%$ recorded for webbased application for universities.

With regards to e-Government awareness in The Gambia, Figure 2 shows that 59.7\% of the respondents were not even aware of Gambia's e-Government, while 29.9\% of the participants were aware of e-Government in The Gambia, with $10.4 \%$ of the respondents probably (maybe) aware. Also, 55.1\% of the participants disagreed that the government is fulfilling its responsibility to make people aware and educate them about the existence of e-Government, $21.7 \%$ of the participants strongly disagreed, $17.4 \%$ yielded neutral, $4.3 \%$ agreed and $1.4 \%$ strongly agreed. With such a high percentage number of citizens unaware of the e-Government web portal (i.e. www.gambia.gov.gm) should be a concern for The Gambia government. The support of local languages would also enhance the understanding of e-Government services. From the survey data, $32.8 \%$ of the participants strongly agreed that the use of local language 
would be helpful to understand the content of e-Government services while $32.8 \%$ of the respondents agreed respectively. 17.9\% yielded neutral; $9 \%$ of the respondents disagreed and 7.5\% strongly disagreed. The Gambia government ought to embark on massive public sensitization on not only the availability of e-Government but also the benefits that the citizens can derive from utilizing such e-Services. e-Government is citizen-centric and its successful adoption squarely centers on citizens' ability to use e-Services.

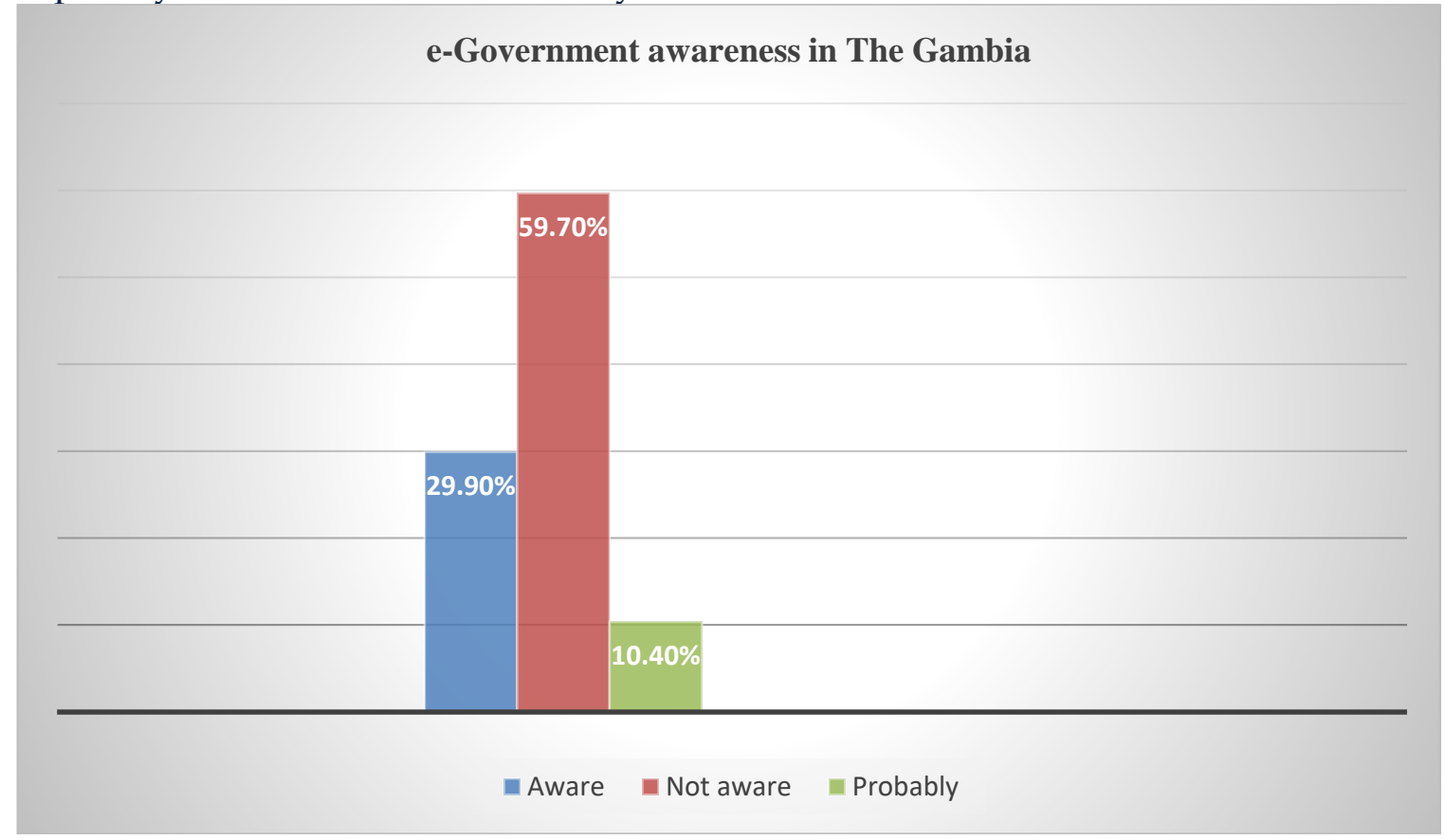

Fig. 2. e-Government awareness in The Gambia

Compared to the traditional way of dealing with the government, e-Governance provides the citizens with the opportunity to improve quality service provision and can also save a lot of time. According to the survey conducted, 50.7\% of the participants strongly agreed that eGovernment can save time compare to the traditional way of dealing with the government; $32.8 \%$ of the respondents agreed; $11.9 \%$ neutral, $1.5 \%$ disagreed, and $3 \%$ of the participant strongly disagreed. Equally, Figure 3 indicates that $43.3 \%$ of the respondents agreed that eGovernment can improve the service quality they receive; $37.3 \%$ of the participant strongly agreed; $13.4 \%$ were neutral, $1.5 \%$ disagreed and $4.5 \%$ strongly disagreed. e-Government services can make it easier to do tasks such as online tax payment, passport, and ID card renewals, etc, with $46.3 \%$ of the participants strongly agreed while $41.8 \%$ of the respondents agreed. These figures show that citizens are aware of the potential benefits e-Government offer as compare to the classical way of dealing with government. 


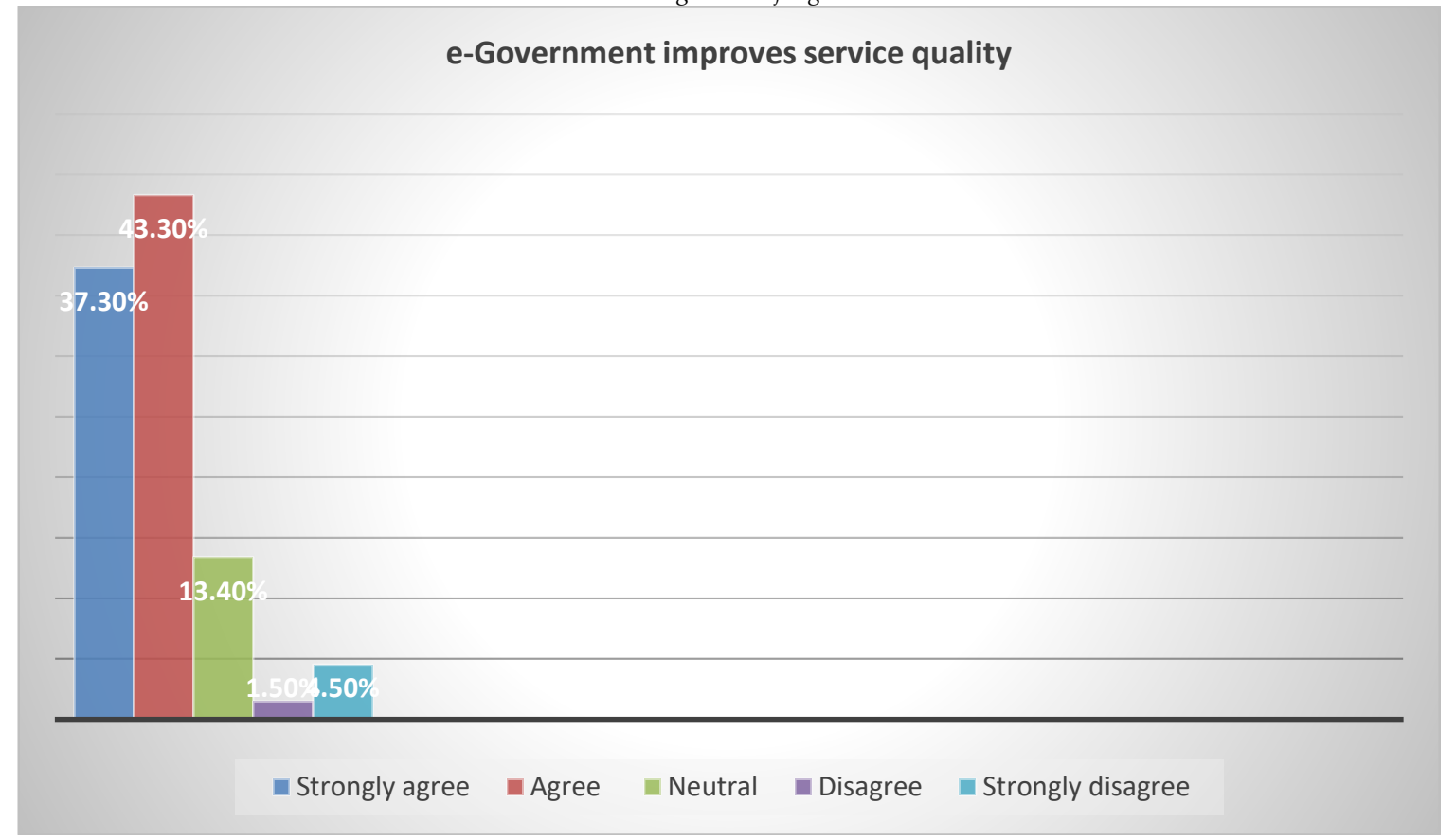

Fig.3. E-Government improves the quality of services

For successful adoption of e-Government, government websites should provide valuable services for the citizens and enhance effectiveness in searching for and using government services such as license renewal, filling forms, etc. The statistic indicates that $37.3 \%$ of the respondents strongly agreed that e-Government websites would provide valuable services; $32.8 \%$ of the participants agreed; $19.4 \%$ yielded neutral; $6 \%$ disagreed and $4.5 \%$ strongly disagreed. These results show that website design and quality are highly valued by citizens. The state of government websites can enhance effectiveness in searching and using government services. The survey conducted supports this claim with $50.7 \%$ of the respondents agreed while $32.8 \%$ of the participants strongly agreed.

According to the survey conducted, $46.3 \%$ of the participants agreed that political and bureaucratic supports would enhance trust and adoption of e-Government. $32.8 \%$ of the respondents agreed with political and bureaucratic supports; $13.4 \%$ yielded neutral; $4.5 \%$ strongly disagreed and 3\% of the respondents disagreed. These statistics highlight the significance of political and bureaucratic endorsement in the adoption and trust-building of eGovernment initiatives. This finding is also congruent with (Bojang, 2020) who concludes that eGovernment adoption would be incomplete without leadership and bureaucratic supports. With strong leadership commitment driven by the innovative public policy will spur eGovernment adoption and hence create public value for citizens.

The respondents were asked whether The Gambia government provides adequate facilities such as ICT hub, service centers, or internet cafes to access e-Government services, and 100\% of the participants responded ' $\mathrm{No}^{\prime}$. A simple explanation for the government's inability to provide basic facilities is because e-Government has not been a priority coupled with the fact that adopting innovation in an environment where it has no reality to most of those who live there. Besides, e-Government calls for a more transparent and accountable government, a principle that is not cherished by The Gambia government. Although the respondents in the survey 
indicate that the government of The Gambia provides no resources to facilitate the use of eGovernment, $50 \%$ of the participants claimed to have the necessary resources at work or at home to use e-Government services while 35.3\% of the participants indicate not to have the necessary resources to utilize e-Government at home or work and $14.7 \%$ yielded probably. Further, $72.5 \%$ of the participants argued to know the necessity to use e-Government services while $11.6 \%$ claimed not to have the necessary skills to utilize e-Government and $15.9 \%$ of the respondents probably. The survey data also shows that the government is not giving the citizens training to make the best use of online services. The Gambia government should integrate information technology and computing at the early stage of the school curriculum. Computer skill centers, adult education centers should be opened length and breadth of the country to educate and train people on how to use various e-Services. This will inculcate eLifestyle among citizens and hence spur e-Government adoption.

For the successful adoption of e-Government, trust and reliability are very important. From the conducted survey, $42 \%$ of the respondents agreed that e-Government services are more reliable to deal with than traditional systems, $34.8 \%$ of the participants strongly agreed, $17.4 \%$ neutral, $2.9 \%$ disagreed and 2.9\% strongly disagreed. Equally, many of the participants also strongly agreed or agreed (29\% and $49.3 \%$ respectively) that e-Government services respond to citizens' needs quickly. Concerning the trust issue, $43.5 \%$ of the respondents were found to be neutral on the risky nature of e-Government use, 34.8\% of the participants disagreed, 15.9\% strongly disagreed, $4.3 \%$ agreed and 1.4\% strongly agreed. Many of the respondents were also concerned over the possibility of hackers intruding on government service and steal their personal information which yielded $46.4 \%$ of the respondents. The result from the survey indicates that $42 \%$ of the respondents do not feel assured of the adequacy of the legal and technological structure, while $34.8 \%$ of the participants were not sure. With e-Government adoption and implementation, necessary safety measures should be taken to protect personal data in government, and security and privacy legislation should be implemented. The security and privacy issues are not only important but necessary pre-conditions for the successful adoption of e-Government. e-Government is a project center on citizens and citizens can only utilize this initiative if they feel secure with the services provided. However, despite trust concerns raised among participants, it is quite interesting to see from the survey that many of the respondents still have faith in an online transaction with the government. The figure indicates that $89.9 \%$ of the participants intend to use e-Government services to get vital information.

\section{Conclusion and policy recommendations}

This study was carried out to identify critical factors that enable citizens' adoption of eGovernment services in The Gambia. Citizens' intention to adopt e-Government initiatives in The Gambia was evaluated comprehensively on the ways and means of transacting business with the government and the quality of the information received. The findings from the survey indicate that awareness creation and quality service provision strongly influence citizens' intention to adopt e-Government services. The survey conducted indicates that citizens are highly concerned about the quality of infrastructure and information provided. Also, citizens 
were concerned about privacy laws and the security of their personal information from been hack by intruders or misuse by a government agency. The government should implement cyber laws to make citizens feel secure and comfortable while they are transacting with the government, which will increase the adoption rate of e-Government services. Political and bureaucratic support and trust in government were also found to be critical factors for the adoption of e-Government in The Gambia. The availability of information, ease to use of government websites, up-to-date information, reliability and quick response from government websites equally influence citizens' intention to adopt e-Government. These findings corroborate with the result of (Bojang, 2020; Lin et al., 2011; Rehman et al., 2012).

e-Government is citizen-centric and the government should focus more on awareness creation on the use and benefits of e-Government. This will boost the adoption of e-Government among citizens. Provision of quality online services, the use of local languages and catering to the needs of disable in website design, and ease to use e-Service would spur the adoption of eGovernment which The Gambia government must not overlook. Most of the citizens in The Gambia are unable to access e-Services because of limited resources. It must be said that The Gambia remains behind the rest of the world in e-Government development, the challenges that it faced in designing and adopting e-Government programs are the most formidable in the world. Adequate provision of facilities such as ICT hubs, service centers, or internet cafes to access e-Government services should be promoted by the government. The Gambia's eReadiness and basic infrastructure need to be reappraised and improved on areas needed. Leadership commitment and bureaucratic support are needed for the successful adoption of eGovernment and the government ought to make e-Government a priority since it promotes efficiency and effective government, enhances citizen participation in the policy-making process, increases citizens' trust in government, and reduce corruption.

Successful e-Government adoption can have a demonstrable and tangible influence on improving citizen participation and quality of life as a result of effective multi-stakeholder partnerships. The Gambia government needs to develop appropriate policy frameworks, supported through e-Government legislation, that are linked to strategic development objectives; focus on awareness, outreach, and training efforts on the less privileged segment of targeted users, particularly women and neglected rural communities; and promote local content and supports local language development.

A significant implication for this study is that it will help policymakers with an informed decision on citizens' needs in terms of e-Government services. Having a sound knowledge about the intention of citizens to adopt e-Government will drive public policy-makers to initiate and formulate policies, strategies that will increase the adoption of e-Government initiatives among citizens. Like any other research, this study has limitations too. The sample size for this study was small and the primary data was collected online which may not represent the whole population because the majority of the participants were experienced internet users and also educated. Therefore, a future study should focus on offline respondents' behavior. The integrated conceptual model needs to be validated and more empirical research is equally needed for more concrete findings. 


\section{Conflict of Interest: The author declares no conflict of interest.}

\section{REFERENCES}

Bakunzibake, P., Klein, G. O., \& Islam, S. M. (2019). E-Government Implementation Process in Rwanda: Exploring Changes in a Sociotechnical Perspective. Business Systems Research, 10(1), 53-73. https://doi.org/10.2478/bsrj2019-0005

Bojang, M. B. S. (2020). A Model Proposal for E-Government Implementation in Africa: Adaptation from Delone and Mclean Information System Model. 20(5).

Bui, T. X., Sankaran, S., \& Sebastian, I. M. (2003). A framework for measuring national e-readiness. International Journal of Electronic Business, 1(1), 3. https://doi.org/10.1504/ijeb.2003.002162

Ceesay, L. B., \& Bojang, M. B. S. (2020). Embracing E-Government during the Covid-19 Pandemic and Beyond: Insights from the Gambia. Global Journal of Management and Business Research: A Administration and Management, 20(13).

Chango, M. (2007). Challenges to e-government in Africa South of Sahara: A critical view, and provisional notes for a research Agenda. ACM International Conference Proceeding Series, 232, 384-393. https://doi.org/10.1145/1328057.1328138

Damascene Twizeyimana, J., Larsson, H., \& Grönlund, Å. (2018). E-government in Rwanda: Implementation, Challenges and Reflections. The Electronic Journal of E-Government, 16(1), 19-31. www.ejeg.com

DeLone, W. H., \& McLean Ephramin R. (2003). info quality,satisfacation,DeLone and McLean Model.pdf. Journal of $\begin{array}{llll}\text { Management Information } & \text { Systems, } & \text { 9-30. }\end{array}$ http://mesharpe.metapress.com/index/PEQDJK46VY52V4Q6.pdf

Heeks, R. (2002). Information systems and developing countries: Failure, success, and local improvisations. Information Society, 18(2), 101-112. https://doi.org/10.1080/01972240290075039

Holden, S. H., Norris, D. F., \& Fletcher, P. D. (2003). Electronic government at the grass roots: Contemporary evidence and future trends. Proceedings of the 36th Annual Hawaii International Conference on System Sciences, HICSS 2003. https://doi.org/10.1109/HICSS.2003.1174305

Ifinedo, P. E. (2005). E-government Initiative in a Developing Country : Strategies and Implementation in Nigeria. 26th McMaster World Congress Management of Electronic Business Hamilton, Ontario, Canada January 19-21, $2005, i$.

Jaeger, P. T., \& Thompson, K. M. (2003). E-government around the world: Lessons, challenges, and future directions. Government Information Quarterly, 20(4), 389-394. https://doi.org/10.1016/j.giq.2003.08.001

Kearns Iain. (2004). Public Value and e-Government.

Lin, F., Fofanah, S. S., \& Liang, D. (2011). Assessing citizen adoption of e-Government initiatives in Gambia: A validation of the technology acceptance model in information systems success. Government Information Quarterly, 28(2), 271-279. https://doi.org/10.1016/j.giq.2010.09.004

Magayane, A. A., Mokua, J. K., \& Lanrong, Y. (2016). Evaluation of the current status of E-government implementation in Tanzania: Government websites perspectives. ACSIJ Advances in Computer Science, 5(2), 47-55.

Morgeson, F. V., Vanamburg, D., \& Mithas, S. (2011). Misplaced trust? Exploring the structure of the e-governmentcitizen trust relationship. Journal of Public Administration Research and Theory, 21(2), 257-283. https://doi.org/10.1093/jopart/muq006

Rehman, M., Esichaikul, V., \& Kamal, M. (2012). Factors influencing e-government adoption in Pakistan. Transforming Government: People, Process and Policy, 6(3), 258-282. https://doi.org/10.1108/17506161211251263

Rey-Moreno, M., \& Medina-Molina, C. (2017). Inhibitors of e-Government adoption: Determinants of habit and adoption intentions. Journal of Innovation and Knowledge, 2(3), 172-180. https://doi.org/10.1016/j.jik.2017.01.001

Rose, J., Persson, J. S., Heeager, L. T., \& Irani, Z. (2015). Managing e-Government: Value positions and relationships. Information Systems Journal, 25(5), 531-571. https://doi.org/10.1111/isj.12052

Sæbø, Ø. (2012). E-government in Tanzania : Current Status. IFIP International Federation for Information Processing, 198-209. 
Srivastava, S. C., \& Teo, T. S. H. (2008). E-government payoffs: Evidence from cross-country data. Selected Readings on Global Information Technology: Contemporary Applications, July, 438-457. https://doi.org/10.4018/978-160566-116-2.ch026

Torres, L., Pina, V., \& Royo, S. (2005). E-government and the transformation of public administrations in EU countries: Beyond NPM or just a second wave of reforms? Online Information Review, 29(5), 531-553. https://doi.org/10.1108/14684520510628918 